\author{
Robert Wiluś \\ Katedra Geografii Miast i Turyzmu \\ Uniwersytet Łódzki \\ ul. Kopcińskiego 31 \\ 90-142 Łódź \\ robwil@geo.uni.lodz.pl
}

\section{SEMINARIUM TERENOWE „WARSZTATY BADAWCZE Z GEOGRAFII TURYZMU", ŁÓDŹ, 6-8 WRZEŚNIA 2002 r.}

W dniach 6-8 września 2002 r. odbyło się kolejne, XIX seminarium terenowe „Warsztaty badawcze z geografii turyzmu". Konferencja tradycyjnie została zorganizowana przez Katedrę Geografii Miast i Turyzmu - Zakład Geografii Turyzmu Uniwersytetu Łódzkiego. Spotkanie odbyło się w Łodzi w gmachu Collegium Geographicum, gdzie od roku 1999 znajduje się siedziba Katedry Geografii Miast i Turyzmu. Zgodnie z ustaloną już od wielu lat tradycją celami konferencji były:

1) prezentacja nieopublikowanych do czasu seminarium prac związanych $\mathrm{z}$ aktualnymi problemami badawczymi z zakresu geografii turyzmu i szeroko rozumianej turystyki,

2) omówienie pojęć stosowanych w naukach o turystyce (sesje terminologiczne),

3) prezentacja prac doktorskich z zakresu turystyki ukończonych w roku poprzedzającym seminarium,

4) prezentacja tematyki prac magisterskich wykonanych w różnych ośrodkach w Polsce w ostatnich latach.

Organizacja seminarium w gmachu Collegium Geographicum pozwoliła na zorganizowanie wystaw poświęconych dorobkowi naukowemu i dydaktycznemu Katedry Geografii Miast i Turyzmu UE. Na wystawach prezentowane były prace naukowe pracowników (artykuły, książki, prace doktorskie, habilitacyjne, podręczniki itd.) oraz studentów (prace magisterskie) Uniwersytetu Łódzkiego związanych z Katedrą Geografii Miast i Turyzmu. Celem zorganizowania tych wystaw było umożliwienie uczestnikom konferencji zapoznania się z osiagnięciami naukowo-dydaktycz-

\section{THE 19 ${ }^{\text {TH }}$ FIELD SEMINAR - 'RESEARCH WORKSHOPS ON THE GEOGRAPHY OF TOURISM': ŁÓDŹ, 6-8TH SEPTEMBER 2002}

The $19^{\text {th }}$ field seminar 'Research Workshops on the Geography of Tourism' took place from September 6-8 2002. The conference was organized by the Department of Urban and Tourism Studies, Faculty of Geography, University of Łódż, at the Collegium Geographicum (the seat of the Department since 1999). Traditionally, the aims of the conference are:

1) presentation of unpublished works concerning research into the geography of tourism and tourism in general,

2) discussion of terms used in tourism studies (terminology sessions),

3) presentation of doctoral theses on tourism completed in the preceding year,

4) presentation of MA theses completed in different centres in Poland in recent years.

The fact that the seminar took place in the Collegium Geographicum allowed the organizers to prepare exhibitions devoted to the academic achievements of the Dept of Urban and Tourism Geography. The exhibitions presented academic publications by department members (articles, books, doctoral theses, textbooks, etc.) and students (MA theses). In this way conference participants could learn about the achievements of an institution which has been organizing research workshops on the geography of tourism for 19 years. 
nymi instytucji, która już od 19 lat jest organizatorem warsztatów badawczych $\mathrm{z}$ geografii turyzmu. Wystawy zostały przygotowane przez dr Jolantę Latosińską i dr. Bogdana Włodarczyka z Uniwersytetu Łódzkiego.

Seminarium składało się z czterech sesji, podczas których wygłoszono 14 referatów. Każda sesja kończyła się dyskusją. W czasie pierwszej sesji, której przewodniczyła prof. dr hab. Elżbieta Dziegieć, uwaga referentów skupiona była na definiowaniu „regionu turystycznego”. Jako pierwszy przemyślenia dotyczące tego pojęcia przedstawił doc. Adam Bajcar z Wyższej Szkoły Turystyki i Hotelarstwa z Warszawy. W wystapieniu A. Bajcar zwrócił uwagę na znaczenie istnienia regionu turystycznego w rozwoju współczesnej turystyki. W drugim ivystapieniu prof. dr hab. Stanisław Liszewski z Uniwersytetu Łódzkiego zaprezentował autorski pogląd nt. pojęcia „region turystyczny". Stwierdził on, że region turystyczny istnieje tylko wtedy, kiedy koncentruje się w nim ruch turystyczny. Jednocześnie S. Liszewski uznał, że dla wyznaczania regionu turystycznego drugorzędne znaczenie mają walory turystyczne. Ostatecznym weryfikatorem atrakcyjności turystycznej obszaru jest człowiek (turysta), który uznaje, co dla niego jest atrakcyjne pod względem wypoczynkowym i poznawczym. Ostatnie wystapienie w pierwszej części sesji terminologicznej prof. dr. hab. Marina Bachvarowa $z$ Uniwersytetu Łódzkiego było próbą zdefiniowania pojęcia "region turystyczny” na podstawie przeglądu dotychczasowych definicji tego terminu. Autor zwrócił uwage na czasowe istnienie regionu turystycznego, zależne od zmieniających się potrzeb człowieka w zakresie szeroko rozumianej turystyki. W czasie przerwy czynne były wspomniane wcześniej wystawy prezentujące dorobek naukowo-dydaktyczny Katedry Geografii Miast i Turyzmu Uniwersytetu Łódzkiego.

Drugą część sesji terminologicznej, której przewodniczył prof. dr hab. Stanisław Liszewski z Uniwersytetu Łódzkiego, rozpoczął referat $\mathrm{dr}$ Małgorzaty Durydiwki i prof. dr. hab. Andrzeja Kowalczyka z Uniwersytetu Warszawskiego. Wystąpienie generalnie dotyczyło problemów związanych $\mathrm{z}$ wyznaczaniem regionu turystycznego w okresie narastającego procesu globalizacji. Autorzy twierdzą, że coraz trudniej jest dziś mówić o regionie turystycznym, kiedy decydujące o jego istnieniu wartości ulegają coraz większej unifikacji, a ruch turystyczny praktycznie występuje wszędzie. Z kolei mgr Piotr Zmyślony z Aka-
The exhibitions were prepared by Dr Jolanta Latosinsska and Bogdan Włodarczyk (Univ. of Łódź).

The seminar was divided into four sessions comprising 14 presentations. Each session was followed by a discussion. The first, led by Prof. Elżbieta Dziegieć, was devoted to the definition of a tourist region and the first speaker was Adam Bajcar (Higher School of Tourism and Hotel Management in Warsaw). He paid particular attention to the significance of a tourist region in the development of contemporary tourism. In the next presentation, Prof. Stanisław Liszewski (Univ. of Łódź) presented his original concept of a tourist region according to which it exists only if tourist activity takes place. At the same time Prof. Liszewski claimed that tourist assets are of secondary importance for delimiting a tourist region and the ultimate verifier of an area's tourist attractiveness is man (the tourist) who decides what is attractive for him. The last presentation was given by Prof. Marin Bachvarov (Univ. of Łódż) who attempted to construct a definition of a tourist region on the basis of the definitions formulated so far. The author drew the listeners' attention to the temporary existence of a tourist region depending on changing human needs regarding tourism in general. During the break the participants could visit the exhibitions mentioned earlier.

The second session on terminology, led by Prof. Liszewski, began with a presentation by Dr Małgorzata Durydiwka and Prof. Andrzej Kowalczyk (Warsaw Univ.) concerning the issues of delimiting a tourist region in an era of growing globalisation. The authors claim that it is becoming increasingly difficult to speak about a tourist region now that its determining elements are becoming more and more unified, and tourism occurs practically everywhere. In his presentation Piotr Zmyślony (Academy of Economics in Poznań) claimed that a tourist region is an economic notion, and its existence depends on the economic value of its elements - assets, attractions, tourist institutions and organizations, etc. 
demii Ekonomicznej w Poznaniu w swoim wystąpieniu stwierdził, że region turystyczny jest pojęciem ekonomicznym, a jego istnienie zależy od ekonomicznej wartości elementów go tworzących - walorów, atrakcji, instytucji i organizacji turystycznych itd.

Temat sesji terminologicznej wywołał żywą dyskusję wśród uczestników seminarium - od poglądów skrajnych, że w dobie globalizacji termin "region turystyczny” traci sens, po głosy afirmujące istnienie regionu turystycznego. Zastanawiano się, czy region turystyczny istnieje w rzeczywistości, czy jest tylko pojęciem intelektualnym, narzędziem analitycznym, jakie są różnice pomiędzy regionem ekonomicznym a turystycznym. W dyskusji zwrócono także uwage na to, czy geografia turyzmu powinna zajmować się regionalizacją turystyczną czy też winno się stosować to pojęcie bez kontekstu teoretycznego.

Po sesji terminologicznej tego samego dnia po południu zaplanowano zwiedzanie Łodzi. Wycieczkę poprzedził wykład prof. dr hab. Elżbiety Dziegieć (Uniwersytet Łódzki) nt. „Wielkie miasto jako obiekt turystyczny. Przykład Łodzi”. Trasa wycieczki pt. „Szlakiem rozwoju przestrzenno-funkcjonalnego Łodzi" prowadziła przez najważniejsze miejsca związane $\mathrm{z}$ historią Łodzi przemysłowej. Wycieczka została przygotowana i poprowadzona przez dr dr Beatę Krakowiak i Jolantę Wojciechowską z Uniwersytetu Łódzkiego.

Następnego dnia, w sobotę 14 września, odbyła się pierwsza sesja warsztatowa, w której zaprezentowano trzy wystapienia. Dotyczyły one koncepcji „15 p” marketingu turystycznego, którą zaprezentował dr Jacek Kaczmarek z Uniwersytetu Łódzkiego, modeli lokalizacji usług gastronomicznych na obszarach miejskich - mgr Agnieszki Kaczorek i prof. dr. hab. Andrzeja Kowalczyka z Uniwersytetu Warszawskiego oraz znaczenia turystyki jako czynnika lokalnego rozwoju zaprezentowane przez mgr Joannę Małek z Uniwersytetu Warszawskiego. Przewodniczącym tej sesji był prof. dr hab. Marin Bachvarov.

Podczas drugiej sesji warsztatowej, pod przewodnictwem prof. dr. hab. Andrzeja Kowalczyka, dr Dana Fialova z Uniwersytetu Karola w Pradze Czeskiej mówiła o rozwoju nowych form osadnictwa letniskowego w Republice Czeskiej. Następnie dr Robert Brudnicki z Uniwersytetu Mikołaja Kopernika w Toruniu przedstawił wyniki ukończonej w tym roku swojej pracy doktorskiej dotyczącej społeczno-ekonomicznych uwa-
The theme of the terminology session raised a heated discussion among the seminar participants whose opinions ranged from those who claimed that in the globalization era a tourist region as such loses meaning to those who assert the existence of a tourist region. There was discussion whether a tourist region exists in reality or whether it is only an intellectual notion, an analytical tool, and what the differences are between an economic and a tourist region. A question was also raised whether the geography of tourism should deal with tourist regionalization, or whether perhaps the term should be used without any theoretical context.

The next part of the seminar included an excursion around Łódź, preceded by a lecture "A Large City as a Tourist Site: the example of Łódż" delivered by Prof. Dziegieć. The excursion, entitled "Following the Spatial-Functional Development of Łódź", went through the most important places related to its industrial history, and was prepared and led by Dr Beata Krakowiak and Dr Jolanta Wojciechowska (Univ. of Łódź).

On the next day, Saturday $14^{\text {th }}$ Sept, the first workshop took place with three presentations: the ' $15 \mathrm{P}^{\prime}$ tourist marketing concept, presented by $\mathrm{Dr}$ Jacek Kaczmarek (Univ. of Łódż), models of catering service location in urban areas, presented by Agnieszka Kaczorek and Prof. Andrzej Kowalczyk (Warsaw Univ.), and the importance of tourism as a local development factor, presented by Joanna Małek (Warsaw Univ.). The session was presided over by Prof. Marin Bachvarov.

During the second workshop session, headed by Prof. Andrzej Kowalczyk, Dr Dana Fialova (Charles Univ. in Prague) talked about the development of new summer settlement forms in the Czech Republic, followed by Dr Robert Brudnicki (Nicolaus Copernicus Univ. in Toruń) presenting the results of his doctoral work completed this year concerning the socioeconomic conditions of tourist recreational behaviour among Torun's inhabitants. The final presentation was delivered by $\mathrm{Dr}$ Barbara Pisarska who discussed opport- 
runkowań zachowań turystyczno-wypoczynkowych mieszkańców Torunia. Jako ostatnia w tej sesji wystapiła dr Barbara Pisarska, która zajęła się w swoim wystapieniu moźliwościami rozwoju edukacji przyrodniczo-kulturowej $w$ obrębie obszarów chronionych.

Na zakończenie odbyła się trzecia sesja warsztatowa, która została praktycznie zdominowana przez pracowników Zakładu Geografii Turyzmu Uniwersytetu Łódzkiego. Pierwsze wystapienie tej sesji dr Jolanty Latosińskiej i dr. Bogdana Włodarczyka dotyczyło charakterystyki potencjału turystycznego Pojezierza Sławskiego. W drugim wystapieniu dr dr Beata Krakowiak i Bogdan Włodarczyk przedstawili projekt oferty turystycznej związanej z oryginalnymi atrakcjami turystycznymi ziemi chojeńskiej. Referat ten został uzupełniony o wypowiedź dr Przemysława Kołosowskiego z Uniwersytetu Mikołaja Kopernika w Toruniu, który mówił głównie o atrakcjach archeologicznych tego terenu. Ostatnie wystapienie, dr. Roberta Wilusia, dotyczyło rzek jako przedmiotu badań geografii turyzmu. Sesji tej przewodniczył prof. dr hab. Andrzej Matczak z Uniwersytetu Łódzkiego.

Ogółem w XIX seminarium terenowym „Warsztaty badawcze z geografii turyzmu" wzięło udział 45 osób z ośmiu ośrodków naukowych w Polsce (Uniwersytetów: Jagiellońskiego, Warszawskiego, Adama Mickiewicza w Poznaniu, Szczecińskiego i Mikołaja Kopernika w Toruniu, a także Akademii Ekonomicznej w Poznaniu, Akademii Rolniczej w Poznaniu, Pomorskiej Akademii Pedagogicznej w Słupsku) z prywatnej Wyższej Szkoły Turystyki i Hotelarstwa w Łodzi i w Warszawie oraz z jednego zagranicznego Uniwersytetu Karola w Pradze. Opiekę merytoryczną nad seminarium sprawowała prof. dr hab. Elżbieta Dziegieć, a sekretarzem naukowym tego spotkania był dr Robert Wiluś.

Nazwiska autorów i tytuły referatów na XIX Seminarium Terenowe „Warsztaty badawcze z geografii turyzmu":

1. Doc. Adam Bajcar (Wyższa Szkoła Turystyki i Hotelarstwa w Warszawie) - Definicja pojecia „region turystyczny”.

2. Prof. dr hab. Stanisław Liszewski (Uniwersytet Łódzki) - Pojęcie „regionu turystycznego”.

3. Prof. dr hab. Marin Bachvarow (Uniwersytet Łódzki) - Regionalizacja turystyczna - nowa treść $w$ starej formie.

4. Dr Małgorzata Durydiwka (Uniwersytet Warszawski), prof. dr hab. Andrzej Kowalczyk unities for development of environmental and cultural education in protected areas.

The third workshop session was dominated by the Dept of Urban and Tourism Geography, Univ. of Łódz. The first presentation by Dr Jolanta Latosińska and Dr Bogdan Włodarczyk concerned the tourist potential of the Sławskie lake district. In the second, Dr Beata Krakowiak and Dr Bogdan Włodarczyk presented a plan for a tourist offer connected with the distinctive tourist attractions in Chojeńska. This presentation was supplemented by $\mathrm{Dr}$ Przemysław Kołosowski (Nicolaus Copernicus Univ. in Toruni) who spoke mainly about the archaeological attractions of this area. The last presentation by Dr Robert Wilus concerned rivers as an object of research in the geography of tourism. The session was led by Prof. Andrzej Matczak (Univ. of Łódż).

The 19th field seminar 'Research Workshops on the Geography of Tourism' was host to 40 participants from eight academic centres in Poland (Jagiellonian Univ., Warsaw Univ., Adam Mickiewicz Univ. in Poznań, Univ. of Szczecin, Nicolaus Copernicus Univ. in Toruń, Academy of Economics and Academy of Agriculture in Poznań, Pomeranian Academy of Pedagogy in Słupsk), and also the private Higher School of Tourism and Hotel Management in Łódż and Warsaw, as well as the Charles Univ. in Prague. Prof. Elżbieta Dziegieć supervised the seminar, and Dr Robert Wiluś was the seminar secretary.

Authors and titles of presentations:

1. Dr habil. Adam Bajcar (Higher School of Tourism and Hotel Management in Warsaw) - The definition of the term tourist region.

2. Prof. Stanisław Liszewski (Univ. of Łódź) - The concept of a tourist region.

3. Prof. Marin Bachvarov (Univ. of Łódź) - Tourist regionalization - a new meaning in an old form.

4. Dr Małgorzata Durydiwka (Warsaw Univ.) \& Prof. Andrzej Kowalczyk (Univ. of Łódź) - The tourist region and globalization processes. 
(Uniwersytet Łódzki) - Region turystyczny, a procesy globalizacji.

5. Mgr Piotr Zmyślony (Akademia Ekonomiczna w Poznaniu) - Region turystyczny w ujęciu ekonomicznym.

6. Dr Jacek Kaczmarek (Uniwersytet Łódzki) - „15 P" marketingu turystycznego.

7. Mgr Agnieszka Kaczorek, prof. dr hab. Andrzej Kowalczyk (Uniwersytet Warszawski) - Modele lokalizacji ustug gastronomicznych na obszarach miejskich.

8. Mgr Joanna Małek (Uniwersytet Warszawski) - Turystyka jako czynnik rozwoju lokalnego.

9. Dr Dana Fialova (Uniwersytet Karola w Pradze) - Vystavba novych objektu - replik puvodnich roubenych chalup.

10. Dr Robert Brudnicki (Uniwersytet Mikołaja Kopernika w Toruniu) - Spoteczno-ekonomiczne uwarunkowania zachowań turystycznowypoczynkowych mieszkańców Torunia.

11. Dr Barbara Pisarska - Możliwości edukacji przyrodniczo-kulturowej w obrębie obszarów chronionych $w$ Polsce.

12. Dr Jolanta Latosińska, dr Bogdan Włodarczyk (Uniwersytet Łódzki) - Potencjat turystyczny Pojezierza Stawskiego.

13. Dr Beata Krakowiak, dr Bogdan Włodarczyk (Uniwersytet Łódzki) - Oryginalność walorów antropogenicznych jako potencjalny czynnik kreowania produktu turystycznego ziemi chojeńskiej.

14. Dr Robert Wiluś (Uniwersytet Łódzki) Rzeki-przedmiot badań geografii turyzmu.
5. Piotr Zmyślony MA (Academy of Economics in Poznañ) - Economic aspects of tourist regions.

6. Dr Jacek Kaczmarek (Univ. of Łódż) The 15 P of tourist marketing.

7. Agnieszka Kaczorek \& Prof. Andrzej Kowalczyk (Warsaw Univ.) - Models of catering service location in urban areas.

8. Joanna Małek (Warsaw Univ.) Tourism as a local development factor.

9. Dr Dana Fialova (Karel Univ. in Prague) - Vystavba novych objektu - replik puvodnich roubenych chalup.

10. Dr Robert Brudnicki (Nicolaus Copernicus Univ. in Toruñ) - Socioeconomic conditions of tourist recreational behaviour among Torun's inhabitants.

11. Dr Barbara Pisarska - Opportunities for environmental and cultural education in protected areas in Poland.

12. Dr Jolanta Latosinska \& Dr Bogdan Włodarczyk (Univ. of Łódż) - The tourist potential of the Stauskie Lake District.

13. Dr Beata Krakowiak \& Dr Bogdan Włodarczyk (Univ. of Łódż) - The distinctiveness of anthropogenic assets as a potential factor in creating a tourist product in Chojenska.

14. Dr Robert Wiluś (Univ. of Łódż) Rivers: an object of study in the geography of tourism. 